\title{
Experimental transmission of white spot syndrome virus (WSSV) from black tiger shrimp Penaeus monodon to the sand crab Portunus pelagicus, mud crab Scylla serrata and krill Acetes sp.
}

\author{
K. Supamattaya ${ }^{1, *}$, R. W. Hoffmann ${ }^{2}$, S. Boonyaratpalin ${ }^{3}$, P. Kanchanaphum ${ }^{4}$ \\ ${ }^{1}$ Department of Aquatic Science, Faculty of Natural Resources, Prince of Songkla University, Hat Yai 90110, Thailand \\ ${ }^{2}$ Institute of Zoology, Fisheries Biology and Fish Disease, Kaulbachstr. 37, D-80539 Munich, Germany \\ ${ }^{3}$ Department of Fisheries, Kaset Klang, Bangkhen, Jaturjak 10900, Thailand \\ ${ }^{4}$ Department of Biochemistry, Faculty of Science, Mahidol University, Bangkok 10400, Thailand
}

\begin{abstract}
White spot syndrome virus (WSSV) is the cause of a widespread epizootic in cultured shrimp in Thailand and many other countries in Asia. A number of crustacean and other arthropod species have been proposed as reservoirs for the virus by feeding trials and PCR assays. However, detailed histological studies are needed to confirm that suspected carriers have active viral infections This study was carried out to determine whether 3 common crustacean residents of shrimp culture ponds (the sand crab Portunus pelagicus, the mud crab Scylla serrata, and krill Acetes sp.) could be experimentally infected with WSSV and, if so, what the effect of these infections would be. For krill, 3 routes of infection were tested (injection, ingestion and immersion) while for the crab species, only injection and ingestion were tested. WSSV preparations were made from naturally and experimentally infected Penaeus monodon as viral extracts from tissue homogenates (for injection and immersion) and as cut tissues (for ingestion). As determined by normal histology, electron microscopy and in situ DNA hybridization, all of the test species could be infected with WSSV. For krill, injection was the most effective route $(100 \%$ mortality in $3 \mathrm{~d})$, followed by immersion (100\% mortality in 5 d) and ingestion ( $20 \%$ mortality in 9 d). For the crabs, injection was also the most effective route of infection. However, infection did not necessarily lead to mortality. Mortality for injected sand crabs was $100 \%$ in $8 \mathrm{~d}$ but for mud crabs only $20 \%$ in $9 \mathrm{~d}$. By ingestion exposure, there was no mortality for either species over the $9 \mathrm{~d}$ experimental period, even though infection was confirmed by histological examination. Based on the results of this study, the crab species and krill can be considered as viral reservoirs, since they are able to carry the infection and may persist for significant periods in the shrimp farming environment.
\end{abstract}

KEY WORDS: Viral transmission - White spot syndrome virus · Penaeus monodon - Crab - Krill

\section{INTRODUCTION}

Shrimp exports from Thailand have increased rapidly in the last $10 \mathrm{yr}$ because of expansion in the number of Thai farms. Because Thailand's geographical location, temperature range and water quality are

•E-mail: skidchak@ratree.psu.ac.th exceptionally well suited for shrimp production, in the past few years it has become the world's leading producer of cultivated shrimp. Statistical records of shrimp exported from Thailand in 1992 to 1994 were 163000, 209000 and 250000 metric tons per year, respectively (Lin \& Nash 1996). Although production has increased, many problems have occurred due to diseases from pathogens including protozoa, fungi, bacteria and viruses. Viral diseases, in particular, have 
become an important limiting factor for shrimp production in recent years. Many viral diseases have been reported from shrimp culture in this region. Fegan et al. (1991) and Flegel et al. (1992) reported some common viruses with low virulence such as monodon baculovirus (MBV) and hepatopancreatic parvo-like virus (HPV). These viruses are widespread and have occurred in Thailand for many years. In early 1992, Boonyaratpalin et al. (1993) and Chantanachooklin et al. (1993) found yellow-head virus (YHV), which was highly virulent for black tiger shrimp. Two years later, Kasornchandra et al. (1995) and Wongteerasupaya et al. (1995) reported another highly virulent virus in black tiger shrimp culture which caused even greater losses in the shrimp industry than those caused by YHV in 1992-1993. The causative agent has since been called white spot syndrome baculovirus complex (WSSV) by Lightner (1996), and a serious epizootic of it is now widespread in Asia (Flegel 1997).

Certain organisms such as krill Acetes sp., and other marine shrimp (e.g. banana shrimp Penaeus merguiensis) have been found to be carriers of WSSV in feeding tests with infected shrimp (Supamattaya unpubl. data), but there have been no detailed reports in Thailand on the mechanism of WSSV transmission or on the histology of suspected carriers. This work is needed to prove whether the suspected carriers are actual reservoirs of the virus. Lo et al. (1997) have reported the detection of WSSV in many cultured and captured crustaceans and other arthropods using PCR technology. Such studies can identify suspected reservoir hosts, but more detailed work is required to prove that they are actually infected. This study was carried out to determine whether 3 common crustacean residents of shrimp culture ponds (implicated as carriers by unpubl. feeding trials) can be reservoir hosts for WSSV. In order to do this, experimental infections of WSSV were studied in krill Acetes sp., sand crab Portunus pelagicus and mud crab Scylla serrata.

\section{MATERIALS AND METHODS}

Test animals. Adult krill of 1 to $2 \mathrm{~cm}$ in length were collected from shrimp ponds where there was no report of viral disease. They were stocked at 20 individuals each in $60 \mathrm{l}$ aquaria equipped with a seawater flow-through system and aeration, and were fed with minced fresh fish. Adult sand crabs were collected at the same site as the krill, and adult mud crabs were purchased from fishermen on the east coast of southern Thailand. Crabs with a size range of 50 to $60 \mathrm{~g}$ body weight were kept in an identical system to that of the krill with 5 crabs per aquarium. They were also fed with minced fresh fish.
Viral stock. WSSV was obtained from naturally infected black tiger shrimp Penaeus monodon collected in southern Thailand from January to March 1995. Gill tissue was dissected and homogenized in lobster hemolymph medium (LHM), pH 7.4 (Paterson \& Stewart 1974). The ratio of tissue to LHM was 1:10. After centrifugation at $3000 \times g$ for $10 \mathrm{~min}\left(4^{\circ} \mathrm{C}\right)$, the supernatant was filtered through a $0.22 \mu \mathrm{m}$ sterile membrane which had been coated with $1 \%$ fetal calf serum. Presence of WSSV was confirmed by negative staining with $1 \%$ phosphotungstic acid and viewing under the transmission electron microscope (Jeol 100CX). The stock solution of virus was kept at $-80^{\circ} \mathrm{C}$ until used.

Infection trials. For experimental WSSV infection in krill, specimens were divided into 6 groups as follows. In group 1, 20 individuals were challenged by injecting $10 \mu \mathrm{l}$ of a 1:5000 dilution of the viral stock solution. In group 2, 20 individuals were challenged by immersion for $1 \mathrm{~h}$ with aeration in a 1:1000 dilution of the virus stock solution in sterile seawater. In group 3, 20 individuals animals were challenged by feeding tissues from experimentally WSSV-infected shrimp (gills, lymphoid organs and subcuticular epithelium). Krill were fed 3 times daily for $5 \mathrm{~d}$. Groups 4 to 6 served as controls. In group 4, krill were injected with LHM only, in group 5, they were immersed in sterile seawater and in group 6 , they were fed with minced fish instead of WSSV infected shrimp tissue. The numbers of individuais in each control group were identical to those in the treatment groups.

Mortality of the krill was recorded for $9 \mathrm{~d}$ after beginning the infectivity challenge. Specimens were observed for clinical signs, and moribund and control individuals were fixed for histology by the light and electron microscopes.

For experimental infection in crabs, specimens were divided into 2 sets ( 1 for sand crabs and 1 for mud crabs) of 4 groups as follows. In group 1, 10 crabs were challenged by injecting $0.1 \mathrm{ml}$ of a 1:5000 dilution of the stock virus solution in LHM into the soft tissues of the joint of a swimming leg. Group 2 was challenged by feeding 10 crabs with muscle tissue from the tails of shrimp experimentally infected with WSSV. The tails were cut into small pieces and fed individually to each crab. Each crab received 1 to 2 pieces per meal twice daily for $9 \mathrm{~d}$. Groups 3 and 4 served as controls. Crabs in group 3 were injected with LHM only and those in Group 4 were fed with fresh fish. The numbers of crabs in the test and control groups were identical (10 each). Gross signs and mortality of the 2 species of crabs were recorded daily for $14 \mathrm{~d}$ after beginning the infectivity challenge. Moribund and control crabs were fixed for histology by the light and electron microscopes.

Fixation and tissue processing. Davidson's fixative was injected into the hepatopancreas and muscle of live 
krill $\left(-0.2 \mathrm{ml} \mathrm{krill}{ }^{-1}\right)$ in order to avoid autolysis of those organs. After injection, the whole krill were immersed in the same fixative for $48 \mathrm{~h}$ before further processing. The same fixative was injected into live crabs. After injection gill tissue, heart, muscle and midgut glands were dissected, and immersed in Davidson's fixative for $48 \mathrm{~h}$. Samples were further processed by standard histological methods (Bell \& Lightner 1988).

Electron microscopy. Parallel samples to the histological samples described above were fixed in $2.5 \%$ glutaraldehyde in cacodylate buffer, $\mathrm{pH} 7.4$ at $4^{\circ} \mathrm{C}$ for $24 \mathrm{~h}$. They were then washed in the same buffer and cut into small pieces ( 2 to $3 \mathrm{~mm}^{3}$ ). These tissues were postfixed in $1 \% \mathrm{OsO}_{4}$ for $1 \mathrm{~h}$ and were then dehydrated through an acetone series. They were embedded in Epon-812, and semi-thin sections were cut at 0.5 to $1.0 \mu \mathrm{m}$ thickness and stained with toluidine blue and safranin for viewing with the light microscope. Ultra-thin sections were subsequently cut at 50 to $100 \mathrm{~nm}$ thickness and contrasted with uranyl acetate and lead citrate. They were viewed under an electron microscope (Zeiss EM 109) at $80 \mathrm{kV}$ acceleration.

In situ hybridization tests. Tissue sections processed for normal histology as previously mentioned were used for this test. In situ DNA hybridization was carried out using a digoxigenin-labeled $4.2 \mathrm{kbp}$ specific probe for WSSV, as described by Wongteerasupaya et al. (1996). Negative and positive control slides consisted of tissues from Penaeus monodon uninfected and infected with WSSV, respectively.

\section{RESULTS}

\section{Krill infections}

WSSV-injected krill exhibited red discoloration within 24 to $48 \mathrm{~h}$ post injection of WSSV filtrates, whereas krill injected with LHM only showed no abnormal signs. Mortality of the virus-injected krill was $100 \%$ within $4 \mathrm{~d}$, while it was zero at that time for the LHM-injected control group which suffered 20\% mortality by Day 9 . Krill exposed to WSSV by immersion showed signs of red discoloration and first mortality 3 to $4 \mathrm{~d}$ after the challenge. The mortality by immersion was slower than that by injection, but it still reached $100 \%$ at $5 \mathrm{~d}$ post challenge. At $9 \mathrm{~d}$, no mortality was observed for the krill immersed in sterile seawater. Krill challenged by ingestion showed no gross signs of disease, but there was $20 \%$ mortality by Day 6. The krill survival rates are shown in Table 1.

\section{Crab infections}

WSSV-injected crabs showed no gross signs of typical white spot disease. However, mortality of the sand crab reached $100 \%$ by Day 9 and mortality for the mud crab was $20 \%$ by Day 4 . The animals looked apparently healthy and fed well up to the point of death. No mortality or morbidity was seen in the crabs challenged by ingestion. The crab survival rates are shown in Table 2.

Table 2. Portunus pelagicus and Scylla serrata. Percent survival of sand crab and mud crab after experimental challenge with WSSV by injection and feeding. Group 1. WSSV injection challenge; Group 2, WSSV feeding challenge; Group 3 , injection control; Group 4, feeding control. Number of crabs in each group $=10$

\begin{tabular}{|lccccccccc}
\hline Treatment & \multicolumn{7}{c|}{ Days post challenge } & 7 & 8 \\
& 1 & 2 & 3 & 4 & 5 & 6 & 7 \\
\hline Group 1 & & & & & & & \\
Sand crab & 100 & 60 & 60 & 60 & 50 & 20 & 10 & 0 \\
Mud crab & 100 & 100 & 100 & 80 & 80 & 80 & 80 & 80 & 80 \\
Groups 2 to 4 (sand and mud crabs) & & & & & No mortality \\
\hline
\end{tabular}




\section{Histology}

With the light microscope, the gills and subcutirular epithelial cells of normal krill showed no abnormal structures or sizes. However, for some specimens, epicommensal protozoans like Zoothamnium sp. were present on the gill filaments and gregarines were present in the intestine. In spite of this, the krill exhibited

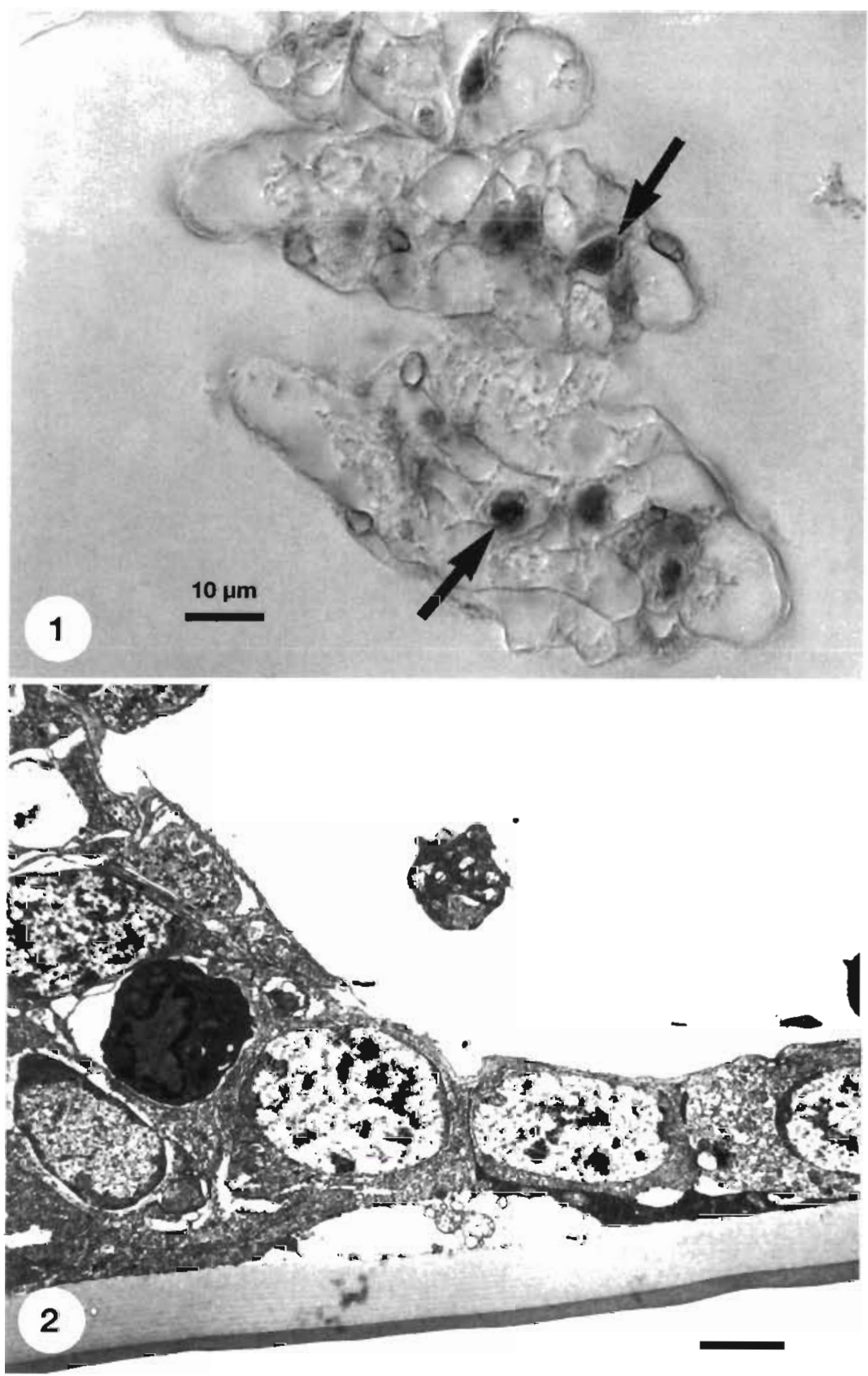

Figs. 1 \& 2. Acetes sp. Histopathology of WSSV-infected krill. Fig. 1 WSSVinfected gill tissue, showing infected cells with hypertrophied nuclei (arrows) (H\&E, scale bar $=10 \mu \mathrm{m})$. Fig. 2. Electron micrograph of the same tissue as in Fig. 1, showing subcuticular epithelial cells with hypertrophied nuclei containing virus particles (uranyl acetate and lead citrate, scale bar $=2 \mu \mathrm{m}$ ) good health. Krill injected with WSSV showed hypertrophied nuclei of hemocytes and pilaster cells along the gill filaments. Hypertrophied nuclei in subcuticular epithelial cells were common (Figs. 1 to 4). No pathological changes were observed in the hepatopancreas of uninfected or infected krill. Nuclear hypertrophy was also observed in the subcuticular epithelia of krill infected with WSSV by ingestion and immersion.

Similar pathological changes were observed in crabs injected with WSSV. Four days after injection, slight changes were observed in gill tissue with some hypertrophy of the nuclei of hemocytes and subcuticular epithelial cells. There was also some degeneration of pilaster cells. By $7 \mathrm{~d}$ after injection, however, these pathological changes were extensive (Fig. 1). For crabs infected by injection, extensive histological changes were also seen in the gill tissue (Figs. $3 \& 4$ ) and even more extensive changes was abserved in regenerating claws (Figs, $5 \& 6$ ).

\section{Electron microscopy}

Electron micrographs of infected krill revealed a bacilliform virus in the hypertrophied nuclei of pilaster cells, hemocytes and subcuticular epithelial cells (Fig. 2). The virus found was similar in size and structure to that detected in WSSV-infected shrimp. Virus particles were detected in the hypertrophied nuclei of all WSSV challenge groups of krill but not in the controls. Crabs gave the same results as krill. Virus particles were found in the hypertrophied nuclei of all WSSV challenge groups (Figs. $7 \& 8$ ) but not in the control groups. Virus particles found in krill and crabs measured 120 to $125 \mathrm{~nm}$ in diameter and 245 to $290 \mathrm{~nm}$ in length.

\section{In situ hybridization}

In addition to the use of electron microscopy to verify the presence of WSBV, a specific DNA probe was used for in situ DNA hybridization tests with tissue sections from paraffinembedded tissues of the krill and 

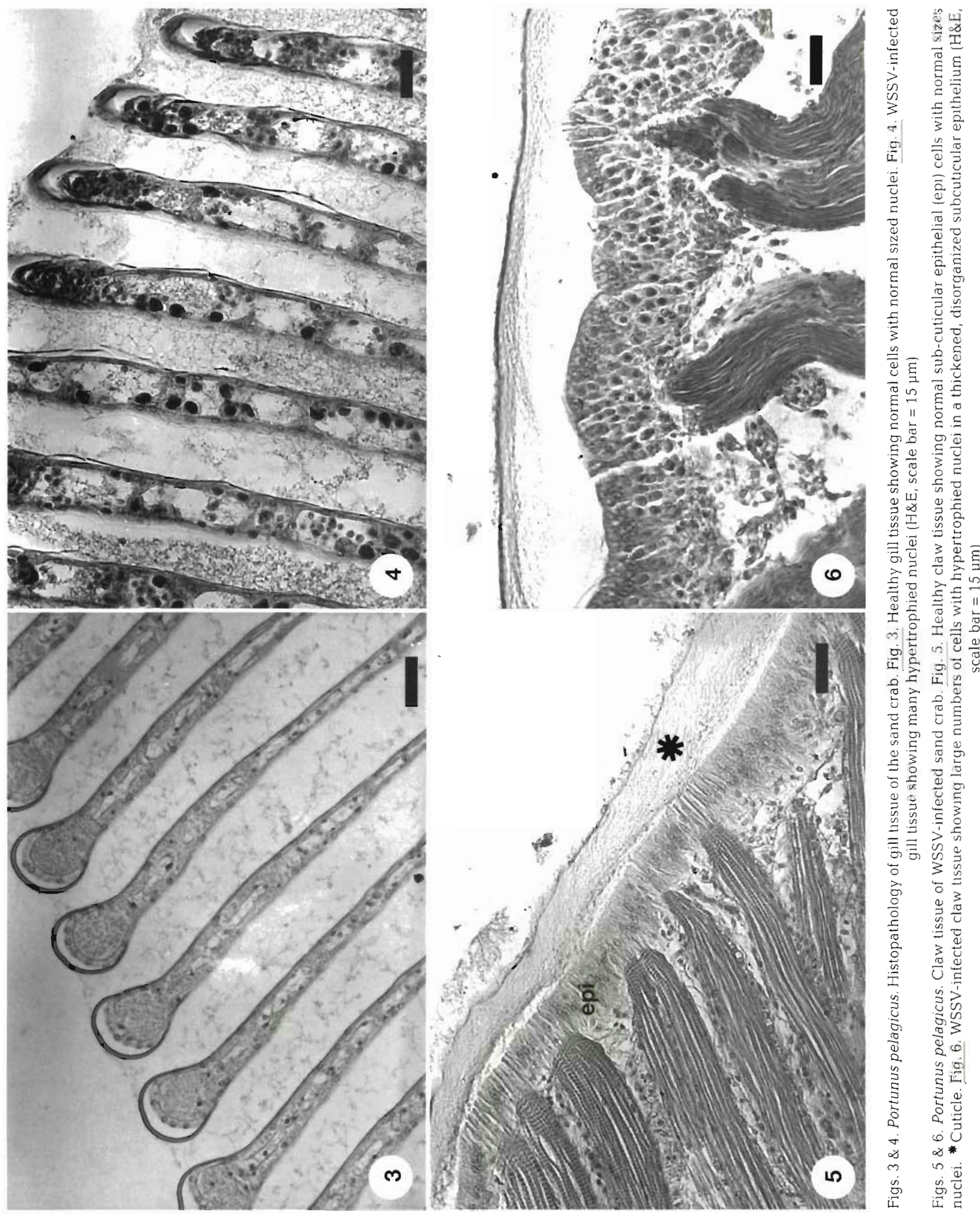


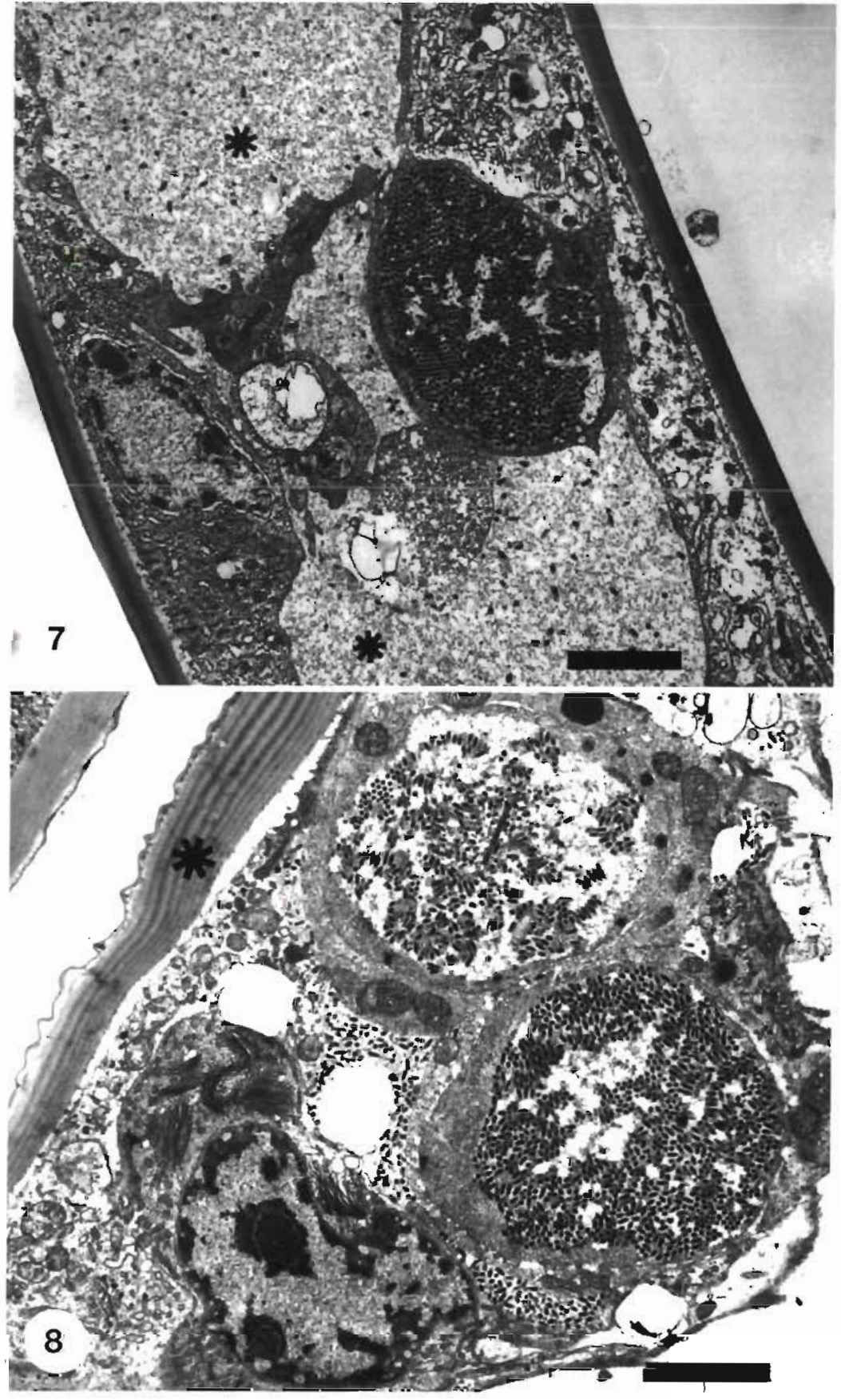

Figs. 7 \& 8. Portunus pelagicus. Electron micrograph of WSSV infected tissue of the sand crab. Fig. 7. WSSV-infected gill tissue showing numerous virus particles in the nucleus of an epithelial cell and free in the hemolymph (asterisks). Fig. 8. WSSV-infected claw tissue showing virus particles in the nuclei of epithelial cells and in the intracellular space. The cuticle is indicated by an asterisk (uranyl acetate and lead citrate, scale bar $=2 \mu \mathrm{m}$ ) monodon tissue served as positive and negative controls for these tests. A sample positive in situ hybridization reaction is shown for mud gill tissue in Fig. 9

\section{DISCUSSION}

Research on WSSV in Thailand has been reviewed by Flegel (1997). In that review, a large number of crustaceans were implicated as possible carriers for WSSV. However, for many of the potential carriers, detailed experimental trials were lacking to indicate whether they were actually infected hosts of WSSV or whether they were only passive mechanical carriers. This study has clearly shown that krill, sand crabs and mud crabs can be active carriers of WSSV. In these tests, krill was obviously more susceptible to the virus than the crabs. It suffered high mortality, similar to that reported for Penaeus monodon when infected with WSSV by similar routes. Because of their rapid mortality, krill would not be able to move far after infection and they may therefore represent a less serious threat to shrimp farms than the crabs, which can apparently carry an active infection for some time without adverse effect.

In the shrimp farming environment, it is known that WSSV can be transmitted to Penaeus monodon via contaminated water and by ingestion of WSSVinfected shrimp tissues (Kasornchandra et al. 1995, Supamattaya et al. 1996). There is also some evidence that it may be transmitted amongst $P$. monodon by cohabitation (Flegel 1997, Flegel et al. 1998), although the specific mode of transfer has not been identified or characterized. Nor has the source of WSSV in contaminated water been identified, although it is possible that shrimp and crabs feeding on carcasses of WSSVinfected shrimp may account for a good part of it.

crabs. All of the tissues showing hypertrophied nuclei characteristic of WSBV infections also gave positive in situ hybridization reactions with the probe. By contrast, tissues from the control krill and crabs did not. Sections of WSBV-infected and non-infected Penaeus
There is little reason to expect that Penaeus monodon would not be infected with WSSV upon ingestion of infected tissue from krill and crabs, just as they are from ingestion of infected $P$. monodon tissue. Indeed, $P$. monodon is known to eat carcasses of krill and other 
crustaceans including $P$. monodon and it was the results from unpublished studies of WSSV infections resulting from krill ingestion (Flegel et al. 1995) that led to this investigation. The question of viral transfer via contact or through the water from living, infected krill and crabs remains open to speculation. However, WSSV transfer from infected to uninfected $P$. monodon (Flegel et al. 1998) and P. japonicus (Maeda et al. 1997) by cohabitation is known to occur, so the likelihood of similar transfer from infected krill and crabs would seem to be high. Taking into consideration recent reports from Taiwan (Lo et al. 1997) and Japan (Maeda et al. 1997) which show that the rate of PCR-detected WSSV in wild crabs can be very high, it would be prudent for shrimp farmers to exclude these potential carriers from the farming system, until it can be established whether they represent a practical danger on the farm.

Acknowledgements. This work was supported by NCGEB Thailand, Aquastar Laboratories Ltd Fund, and a DAAD scholarship to K.S. to Germany during June-August 1995. Thanks to C. Vogt, E. Wanchura, E. M. Rotmann and A. Siebert for their technical assistance.

\section{LITERATURE CITED}

Bell TA, Lightner DV (1988) A handbook of normal penaeid shrimp histology. World Aquaculture Society, Baton Rouge, LA

Boonyaratpalin S, Supamattaya K, Kasornchandra J, Direkbusracom S, Aekpanithanpong U, Chantanachooklin C (1993) Non-occluded baculo-like virus, the causative agent of yellow head disease in the black tiger shrimp (Penaeus monodon). Fish Pathol 28(3):103-109

Chantanachooklin C, Boonyaratpalin B, Kasornchandra J, Direkbusracom S, Ekpanithanpong U, Supamattaya K, Sriurairatana S, Flegel TW (1993) Histology and ultrastructure reveal a new granulosis-like virus in Peneaus monodon affected by 'yellow-head' disease. Dis Aquat Org 17:145-157

Fegan DF, Flegel TW, Sriurairatana S, Waiyakruttha M (1991) The occurrence, development and histopathology of monodon baculovirus in Penaeus monodon in southern Thailand. Aquaculture 96:205-217

Flegel TW (1997) Special topic review: major viral diseases of the black tiger prawn (Penaeus monodon) in Thailand. World J Microbiol Biotech 13:433-442

Flegel TW, Boonyaratpalin S, Withyachumnarnkul B (1998) Current status of research on yellow-head virus and white-spot virus in Thailand. In: Flegel TW, MacRae IH (eds) Diseases in Asian Aquaculture III. Asian Fisheries Soc, China, (in press)

Flegel TW, Fegan DF, Kongsom S, Vuthikornudomkit S, Sriurairatana S, Boonyaratpalin S, Chantanachooklin C, Vickers JE, Macdonald OD (1992) Occurrence, diagnosis and treatment of shrimp diseases in Thailand. In: Fulks W, Main KL (eds) Diseases of cultured penaeid shrimp in Asia and the United States. Proceedings of a workshop in Honolulu, Hawaii, 27-30 April 1992. Oceanic Institute, Hawaii, p 57-112

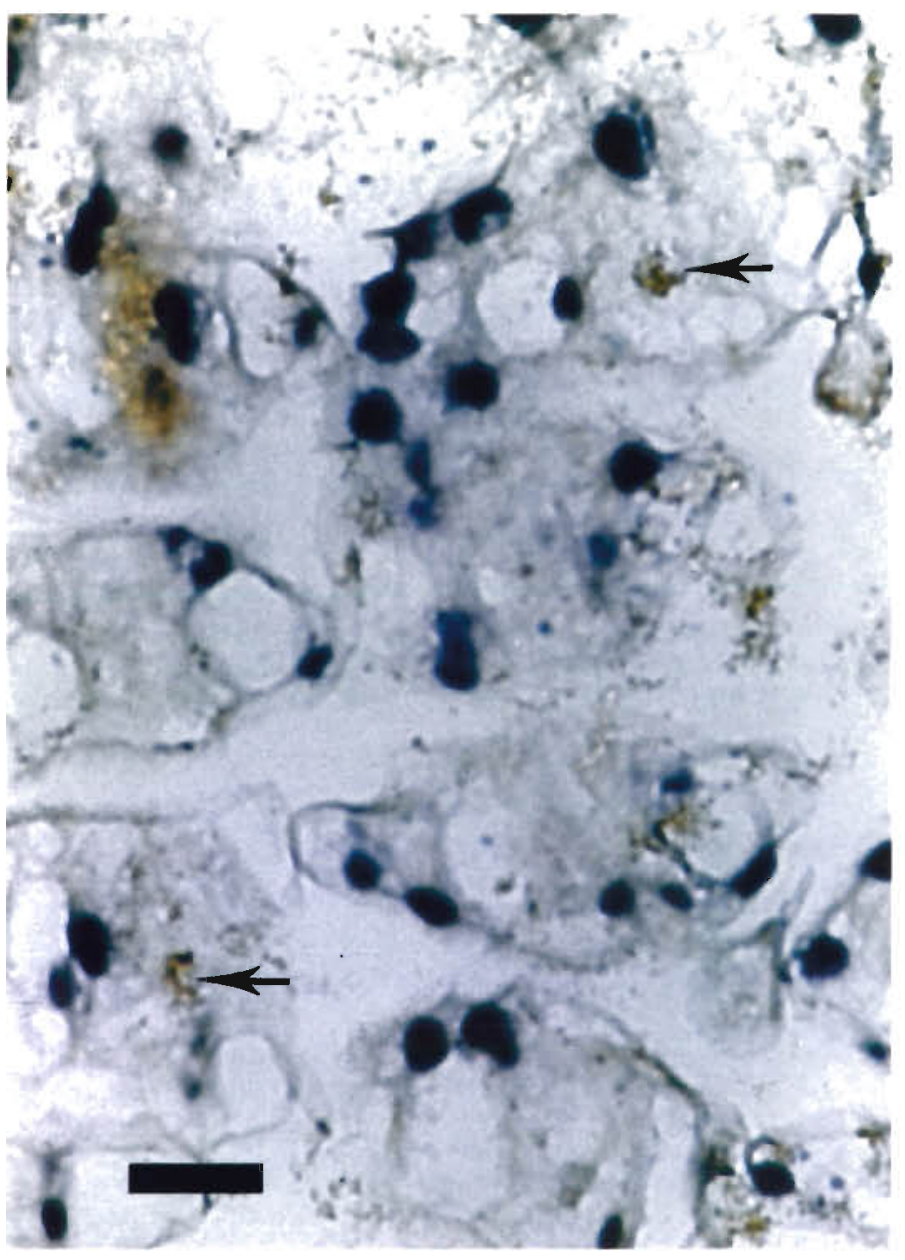

Fig. 9. Scylla serrata. Positive in situ hybridization reaction for WSSV in gill tissue of the mudcrab. Darkly stained nuclei indicate a positive hybridization reaction for the presence of WSSV. Two uninfected, normal nuclei showing no hybridization reaction are indicated by arrows. Scale bar $=15 \mu \mathrm{m}$

Flegel TW, Sriurairatana S, Wongteerasupaya C, Boonsaeng V. Panyim S, Withyachumnarnkul B (1995) Progress in characterization and control of yellow-head virus of Peneaus monodon. In: Browdy C, Hopkins S (eds) Swimming through troubled water. Proceedings of the Special Session on Shrimp Farming, Aquaculture '95, San Diego World Aquaculture Society, Baton Rouge, LA, p 76-83

Kasornchandra J, Boonyaratpalin S, Khongpradit R, Akpanithanpong $U$ (1995) A bacilliform virus, the causative agent of red disease with white patch in black tiger shrimp (Penaeus monodon). Technical paper No. 3/1995, National Institute of Coastal Aquaculture, Kaoseng, Songkla Thailand

Lightner DV (1996) Handbook of pathology and diagnostic procedures for diseases of penaeid shrimp. World Aquaculture Soc, Baton Rouge

Lin CK, Nash G (compilers) (1996) Asian Shrimp News Collected Volume, 1989-1995. Asian Shrimp Culture Council, Bangkok

Lo CF, Wang CH, Kou GH (1997) White spot syndrome (WSS): pathology, hosts and prevalence in captured shrimp and 
crabs in Taiwan. In: Inui Y (ed) New approaches to viral diseases of aquatic animals. NRIA International workshop proceedings. National Research Institute of Aquaculture. Mie, Japan, p 206-217

Maeda M, Itami T, Kondo M, Hennig O, Takahashi Y, Hirono I. Aoki T (1997) Characteristics of penaeid rod-shaped DNA virus of Kuruma shrimp. In: Inui $Y$ (ed) New approaches to viral diseases of aquatic animals. NRIA International Workshop proceedings. National Research Institute of Aquaculture, Mie, Japan, p 218-226

Paterson WD, Stewart JE (1974) In vitro phagocytosis by hemocytes of American lobster (Homarus americanus). J Fish Res Bd Can 31:1051-1056

Supamattaya K, Boonyaratpalin S (1996) The study of histopathology and cytopathological changes in black tiger

Editorial responsibility: Timothy Flegel,

Bangkok, Thailand shrimp (Penaeus monodon) caused by yellow-head virus and red color and white spot disease virus. Songklanakarin J Sci Technol 18(1):17-33

Wongteerasupaya C, Vickers JE, Sriurairatana S, Nash GL, Akarajamorn A, Boonsang V, Panyim S, Tassanakajon A, Withyachumnarnkul B, Flegel TW (1995) A non-occluded, systemic baculovirus that occurs in cells of ectodermal and mesodermal origin and causes high mortality in the black tiger prawn, Penaeus monodon. Dis Aquat Org 21:69-77

Wongteerasupaya $C$, Wongwisansri $S$, Boonsaeng $V$, Panyim S, Pratanpipat P, Nash GL, Withyachumnarnkul B, Flegel TW (1996) DNA fragment of Penaeus monodon baculovirus PmNOBII gives positive in situ hybridization with viral infections in 6 penaeid shrimp species. Aquaculture $143: 23-32$

Submitted: August 29, 1997; Accepted: December 17, 1997 Proofs received from author(s): February 19, 1998 